\title{
Nexus Between Working Capital Management and Sectoral Performance
}

\author{
Suman Talreja ${ }^{1}$, Farhan Ahmed ${ }^{2}$, Raza Ali ${ }^{3}$ \\ Shaheed Zulifikar Ali Bhutto Institute of Science \& Technology \\ ${ }^{1}$ sumantalreja09@gmail.com, ${ }^{2}$ farhan.ahmed@szabist.edu.pk, ${ }^{3}$ raza.ali@lrk.szabist.edu.pk
}

\begin{abstract}
This study aims to examine the impact of aggressive working capital factors/policies on firms' performance to improve the financial health. Random and Fixed Effect models estimated by taking annual data of two major sectors: automobile and food sectors from 2006 to 2016. According to the findings, aggressive investment factor/policy (AIF) has a negative impact on gross operating income (GOI) in both sectors while aggressive financing factor/policy (AFF) has an adverse effect on GOI in the food sector and positive impact on GOI in the automobile sector. The results of this study should be of great importance to investors, creditors, and financial analysts, especially after the global financial crisis and the collapses of giant organizations worldwide.
\end{abstract}

Keywords: working capital management, profitability, non-financial sector

\begin{abstract}
Abstrak
Penelitian ini bertujuan untuk menguji pengaruh faktor/kebijakan modal kerja agresif terhadap kinerja perusahaan untuk memperbaiki kesehatan finansial. Model Random and Fixed Effect diperkirakan dengan mengambil data tahunan dua sektor utama: sektor otomotif dan makanan dari tahun 2006 sampai 2016. Menurut temuan, faktor/kebijakan investasi agresif (AIF) memiliki dampak negatif pada pendapatan operasional kotor di kedua sektor tersebut sementara faktor pembiayaan agresif/kebijakan (AFF) berdampak negatif pada pendapatan operasional kotor di bidang pangan dan dampak positif pada Pemerintah Indonesia di sektor otomotif. Hasil penelitian ini harus sangat penting bagi investor, kreditor, dan analis keuangan, terutama setelah krisis keuangan global dan runtuhnya organisasi raksasa di seluruh dunia.
\end{abstract}

Kata Kunci: manajemen modal kerja, profitabilitas, sektor non-keuangan

\section{Cara Mengutip:}

Talreja, S., Ahmed, F., \& Ali, R. (2018). Nexus Between Working Capital Management and Sectoral Performance. Esensi: Jurnal Bisnis dan Manajemen. Vol. 8 (1): 89 - 104. doi: 10.15408/ess.v8i1.7075. 


\section{INTRODUCTION}

Working capital management is one of the important aspect considered by every organization and its negligence may lead to financial crises of firm. For instance Christopher \& Kamalavalli (2009) recognized that negligence of efficient management of working capital can be dangerous at higher level of any firm. Funds available to a firm or business in order to meets its day to day operations is known as working capital and its inefficacy leads to lower the profitability. Siddique \& Khan (2009) highlighted that inadequate working capital management leads to financial crises as well as negatively effecting a firms profitability, therefore working capital efficiency is important factor for organization in order to maintain survival, liquidity, profitability and solvency. Usama (2012) Working capital is most important factor on which performance of firm mainly and this depends on how company manages it working capital. If a company is unable to manage its working capital in an efficient and effective manner than that company may result in financial crises and lower profitability.

Singh \& Pandey (2016) stated that WCM is important and requires challenging tasks for overall financial management in terms of profitability. The significance of this study is to analyze the impact of WCM on firms' performance and determine the relationship between working capital management and profitability of four sectors of Pakistan.

Monitoring of managerial accounting strategies relating to management of current assets and current liabilities of any firm relates to WCM resulting in efficient financial operations. Working capital management is very important in effective operational processes. Poor working capital management can leads to decrease the financial performance of firm, thus a firm of any sector requires proper monitoring and management of working capital.

Mainly working capital managements is important to ensure that company is able to meet short term debt and short term operating cost through maintaining its flow of cash. Two components current assets and current liabilities represents cash, account receivable, inventory, marketable securities, prepaid expense, short term debts, account payable, accrued liabilities and other liquid assets and debts. Mohamad \& Saad (2010) explained that working assets and liabilities of company referred to working capital of any business are considered as main sources, whereas shortage of cash and credit in any business is threat for a survival of business. However it is difficult for a corporation to survive/ exist without working capital. Eventually working capital management requires short term assets and liabilities related decision. The main purpose of WCM is to ensure that firm has ability to meet or continue its operations with sufficient flow of cash for payment of expenses related to operations and maturing short term debts.

Past researches have highlighted poor profitability as a main reason for inadequate management of working capital. Singhania et al. (2014) conducted a study on 2600 top Asian companies was conducted indicating decline in performance of working capital management. This was due to influence of oil and gas industries and metal and mining industries as this type of company's total sales have significant share. Gill et al., (2010) conducted study of 88 firms of new York list in New York stock exchange from the period of 2005 to 2007 to examine the relationship between profitability and working capital, 
whereas CCC was used as a measure of WCM and GOI for measuring profitability.

Many researches in developing economies are done to investigate the relationship between profitability and working capital management of manufacturing firms such as Arun kumar \& Ramanan, (2013) focused on wider range of manufacturing firms of developing economies to check the relationship of WCM and profitability whereas results indicated profitability boost is result of efficient working capital management.

Working capital by nature deals with short term financing requirements of business. Padachi (2006) in his study indicated that WC is trading capital, "not engaged in the business in a particular form for longer than a year" it is necessary to maintain proper flow of funds as the shortage of funds of many businesses can worsened the financial instability leading to difficulty of firms survival. According to Agha (2014) working capital has direct effect on liquidity and profitability. She described profitability and liquidity as two separate sides of one same coin and explained that liquidity at its optimum level and proper management of funds slow can guarantee a firms profitability.

There are two perspectives to understand working capital policy one is investment perspective and another is financing perceptive. Sharma, (2009) investment perspective involves decision taken by management on the basis of overall investments made in current assets of company. Whereas financing perspective is concerned it refers to financing of current assets from short term debt by a company. Different statements are given by different authors to understand both perspectives of the working capital policy. According to Nazir \& Afza (2009) "aggressive investment policy (AIP) is associated with high risk because holding lower level of current assets will result in inefficient liquidity. Whereas aggressive financing policy is concerned Sharma (2009) explained AFP deals with short term liabilities proportion held by firm benefiting short term liabilities borrowing, low usage conditions and lower rate of interest as compared to long term debt. Implementation of AFP is also related with higher risk because short term loan has short term maturity and must be paid off upon its maturity period thus this leads to increase in profitability of default.

Nazir \& Afza (2009) conducted a study to investigate the impact of working capital policy on profitability of firm and for measuring degree of aggressiveness of working capital policy. It was observed that there is lower ratio of current assets to total assets when management is more aggressive on the other hand when management is flexible towards investment policy, greater proportion will be in invested in current assets resulting in opportunity cost. As far as aggressive financing policy is concerned current liabilities as compared to long term liabilities are utilized more resulting in higher ratio of current liabilities to total assets and in flexible financing policy is concerned more long term liabilities are used.

Working capital management generally involves monitoring of assets, cash flows and liabilities through analyzing key elements. Efficient WCM tends to have improved earnings and profitability of the firm and helps to carry financial operations smoothly. A study regarding Pakistani manufacturing sector showed results highlighting that payment policies and collection problem is faced by manufacturing firms of Pakistan ad found that profitability as well as creating value for shareholders increase with effective and 
efficient WCM. Raheman et al. (2010) said there are two perspectives of understanding policies of working capital management. First one is investment perspective and second one is financing perspective. Tauringana \& Adjapong Afrifa (2013) recommended that companies in order to boost profitability they should focus seriously and by professional mean on WCM Sharma, (2014) suggested that decisions taken by keeping into account the overall investments made in current assets is investment perspective whereas how firm is financing its short term debts and current assets refers to financing perspectives. Zirayawati et al, (2009) quoted that firms positive value can be created by implementation of well-designed WCM.

Many researches have been done previously in developing countries and in Pakistan too to measure working capital management by different means and variables but no work on aggressive working capital policies have been done in Pakistan. Therefore, this study fills the gap to identify the impact of aggressive investment and aggressive financing policies on sectors' performance. This study also helps to identify the effects of additional variables like sales growth, debt ratio, size of firm, liquidity, inventory conversion period, accounts payable periods and cash conversion cycle on Gross Operating Income instead of Return on Assets and Return on Equity. More work can be done to study moderate and flexible aspects of working capital policy.

The financial success or failure of firm in terms of long run is closely related to short term financial performance's success and failure. "Financial theory focuses on long run financial planning with major emphasis on the decision areas of investments, capital structure and dividend policy. "With long-run wealth maximization as the normative criterion, valuation models provide the unifying theme for the development of financial theories related to investment, financing and dividend decisions."

The need to use cash flows from operations in predicting failure has been suggested by in view of Ohlson (1980) suggested that need to use cash flows is that it helps to predict failure from operations. One of the influential theories of corporate leverage is pecking order theory of capital structure which states that new equity, internal funds and debt are the three sources from where financing comes. The theory was initially suggested by Donaldson. Myers and Majluf (1984) further revised the theory and made it popular. According to this to choose financing source there is a hierarchy that a manager need to follow which starts from internal financing to external source of financing. Firm tends to have high market value and increased stock prices with it has higher growth prospect. If growth prospects are not higher it would fail to attract investors which will result in lower market value of the firm. This theory assume no taxes and no bankruptcy costs.

Van Horne \& Wachowicz, (2000) further by explaining in their research stated that there are two main concerns necessary for working capital management and that are management of current assets and current liabilities in a way that will help company to reduce and lower down the risk of inability to meet daily expenses "but also can avoid excessive investment in these assets that may result in loss in form of opportunity cost". However ever firm is responsible for paying of their due obligations on given date. Rehman \& Nasr (2007) found significant negative relationship between firms operational performance and cash conversion cycle, inventory turnover in days and average payment 
period. Samiloglu \& Demirgunes (2008) suggested that by reducing account receivable and account payable period firm can increase profit and they reveled significantly positive relationship between working capital indicators and profitability. Additionally Gill et al (2010) found no significant effect of account payable in days and inventory turnover in day on profitability of firm.

Mojtahedzadeh et al (2011) found that cash conversion cycle, account receivables in days and account payable in days have negative relationship with profitability and found no significant relation between average periods of inventory retention and profitability. Pouraghajan \& Emamgholipourarchi, (2012) identified strongly negative relationship between working capital management variables and profitability. Tauringana \& Adjapong Afrifa (2013) suggested that in order to increase profitability of the firm should increase profitability by serious and professional by giving considerations to issues regarding cash conversion cycle, "which is derived from account receivables days, inventory days and account payable days.

Impact of working capital management on profitability and market valuation of Pakistani firms has been examined by Chang (2012) and his results highlighted positive relationship between total debt to total assets and profitability \& negative relationship of profitability in terms of return on assets and cash conversion cycle. Rahman et al (2010) found that "Sugar and Vanaspati \& Allied Sectors are efficient in terms of managing in working capital but are laggard in term of profitability" and pharmaceutical, cable and electric goods have problem with their inventory management and collection policy so they are categorized into laggard sectors. Khidmat and Rehman (2014) found that solvency ratio has negative and significant relation on impact profitability in terms of return on assets and return on equity. Which means performance decrease if debt to equity ratio increase and liquidity has relatively positive effect on ROA of this sector that means with the increase in liquidity return on assets will increase with greater impact and vice versa. Latif \& Abdullah (2015) found that financial management includes three major issues working capital management, capital budgeting and capital structure, therefore working capital management is major issue from the three of them in financial management. The result of this paper show negative relationship among variables except average payable and gross operating profits.

Under conservative approach financing policy depends more on long term funds for financing needs. The working capital management policy concerns the firms' current assets investment and financing decisions and the policy adopted by a firm could dictate the magnitude of its effect on the firm performance as suggested by Weinraub and Visscher (1998), Salawu \& Ile-Ife (2007), Nazir \& Afza (2009).

Financial decisions and investing in current assets can be approached in three ways that are aggressive, conservative and moderate. Firms chooses one of the approach based on their relative benefits and these approaches are mutually exclusive. A company is categorized as having "aggressive working policy when a company has low proportion of its current assets as a percentage of its total assets and high proportion of its current liability relative to its capital." Company is categorized having conservative working management policy when "it has high proportion its total asset as current asset and low 
proportion of its current liability relative to its total capital". Thus a firm follow to higher risk and higher return when a company is associated to have more aggressive working capital policy and on the other hand lower risk and lower return pattern is followed by firm when a company is likely to follow conservative working capital policy pattern. (Weinraub \& Visscher, 1998).

Abuzayed (2012) found positive relationship between profitability of firm with cash conversion which explained "that firms that have more profit tends to be less motivated for managing their working capital and failure of market to panelize" such firms are with inefficient working capital management. Deloof (2003), Lazaridis \& Tryfonidis (2006), Gill et al. (2010) used gross operating income rather than using depreciation, earnings before interest taxes and amortization as proxy to measure profitability. Additionally Salawu \& IleIfe (2007), Nazir \& Afza (2009) discussed both aggressive investment policy and aggressive financing policy for studying aggressive working capital policy's effects on profitability and for the purpose of measuring efficiency of working capital management, they used cash conversion cycle as a comprehensive measure. Moreover to "investigate the management of each component of CCC, account receivables, account payables and inventory collection period were used.

Working Capital Management is commonly involved in day to day operations of firm and this research has been done in order to examine the impact of working capital managements on firm's profitability of two sectors of Pakistani companies listed in Pakistan stock exchange from the aspect of aggressive working capital policy. This study will conclude the variables influencing efficiency of WCM and effects of different working capital policy on profitability. Sectors selected for this research are food sector and automobiles, very less research have been done in these sectors with context to Pakistan therefore it is necessary to gain knowledge of how different indicators of WC affects profitability of Pakistan. So, the main aim of this research is "to identify the impact of working capital management and profitability with context of Pakistan".

The detailed objectives of the study are: first, to determine the effects of WCM on profitability. Second, to examine the effects of aggressive investment policy on profitability. Third, to examine the effects of aggressive financing policy on profitability. Fourth, to identify the relationship among working capital management and GOI.

\section{METHOD}

This research is quantitative in nature and sampling frame consisted of all non-financial listed companies of Pakistan Stock Exchange and data was collected from Thomson Reuters DataStream. Automobile and food sectors have been selected because of the inelastic aggregate demand and substantial contribution in the economy. Hausman's Specification Test is applied through which random effects and fixed effects were analyzed. The general model equation is given below: 


$$
G O I_{i t}=\beta O+\sum_{\text {all }}^{n} \beta_{i} X_{i t}+\varepsilon
$$

$\mathrm{GOI}_{\mathrm{it}}$ : Gross operating income of firm i at time $\mathrm{t}$; $\mathrm{i}=1,2, \ldots \ldots . . \mathrm{n}$ firms

$\mathrm{X}_{\mathrm{it}}$ : The different independent variables of firm i at time $\mathrm{t}$

$$
\begin{aligned}
& \mathrm{GOI}_{\mathrm{it}}=\alpha+\beta_{1} \mathrm{AIF}_{\mathrm{it}}+\beta_{2} \mathrm{SIZE}_{\mathrm{it}}+\beta_{3} \mathrm{SG}_{\mathrm{it}}+\beta_{4} \mathrm{LIQ}_{\mathrm{it}}+\beta_{5} \mathrm{DR}_{\mathrm{it}}+\mathrm{e}_{\mathrm{it}} \\
& \mathrm{GOI}_{\mathrm{it}}=\alpha+\beta_{1} \mathrm{AFF}_{\mathrm{it}}+\beta_{2} \mathrm{SIZE}_{\mathrm{it}}+\beta_{3} \mathrm{SG}_{\mathrm{it}}+\beta_{4} \mathrm{LIQ}_{\mathrm{it}}+\beta_{5} \mathrm{DR}_{\mathrm{it}}+\mathrm{e}_{\mathrm{it}} \\
& \mathrm{GOI}_{\mathrm{it}}=\alpha+\beta_{1} \mathrm{CCC}_{\mathrm{it}}+\beta_{2} \mathrm{SIZE}_{\mathrm{it}}+\beta_{3} \mathrm{SG}_{\mathrm{it}}+\beta_{4} \mathrm{LIQ}_{\mathrm{it}}+\beta_{5} \mathrm{DR}_{\mathrm{it}}+\mathrm{e}_{\mathrm{it}} \\
& \mathrm{GOI}_{\mathrm{it}}=\alpha+\beta_{1} \mathrm{ICP}_{\mathrm{it}}+\beta_{2} \mathrm{SIZE}_{\mathrm{it}}+\beta_{3} \mathrm{SG}_{\mathrm{it}}+\beta_{4} \mathrm{LIQ}_{\mathrm{it}}+\beta_{5} \mathrm{DR}_{\mathrm{it}}+\mathrm{e}_{\mathrm{it}} \\
& \mathrm{GOI}_{\mathrm{it}}=\alpha+\beta_{1} \mathrm{APP}_{\mathrm{it}}+\beta_{2} \mathrm{SIZE}_{\mathrm{it}}+\beta_{3} \mathrm{SG}_{\mathrm{it}}+\beta_{4} \mathrm{LIQ}_{\mathrm{it}}+\beta_{5} \mathrm{DR}_{\mathrm{it}}+\mathrm{e}_{\mathrm{it}}
\end{aligned}
$$

WhereasGOI is Gross Operating Income, AIF is Aggressive Investment Factor/Policy, AFF is Aggressive Financing Factor/Policy, ICP is Inventory Conversion Period, RCP is Receivables Collection Period, PP is Payable Period, CCC is Cash Conversion Cycle, SIZE is Size of Firm, SG is Sales Growth, DR is Debt RatioandINVD is Inventory Days Held.

\section{RESULT AND DISCUSSION}

This chapter discusses the results and findings of the study for panel data of two nonfinancial sectors (food and automobile sector) from the period of 2006 to 2016, by using panel least square method long with Hausman's Specification Test.

Table 1: Descriptive Statistics of Automobile Sector

\begin{tabular}{ccccc}
\hline Variables & Minimum & Maximum & Mean & SD \\
\hline AIF & 0.310918 & 0.872721 & 0.612524 & 0.138268 \\
AFF & 0.158073 & 1.656469 & 0.540571 & 0.384027 \\
CCC & -12757.67 & 141.3785 & -520.4714 & 2152.891 \\
INVD & 47.00000 & 2141.000 & 218.2727 & 391.5828 \\
REC & 2.000000 & 162864.0 & 6579.745 & 30442.94 \\
PP & 2.763364 & 13850.85 & 758.5361 & 2468.186 \\
DR & 0.000705 & 0.996459 & 0.228487 & 0.293209 \\
SG & 3043.000 & 84542484 & 12494327 & 21595954 \\
SIZE & 3.483445 & 7.927075 & 6.439892 & 0.933975 \\
GOI & -8759.270 & 26.33000 & -312.5442 & 1554.356 \\
\hline
\end{tabular}

This table shows descriptive statistics of variables of Automobile sector.

Table 1 shows descriptive statistics of automobile sector of Pakistan based on data collected from 2006 to 2016 with total of 55 observations. The GOI represents mean value of -312.5442 and standard deviation of 1554.356 with a range of -8759.270 and 26.33000 respectively. The degree of aggressive investment factor shows average mean value of 0.6125 whereas degree of aggressiveness of financing factor shows average mean value of 
0.540. CCC showed negative mean value of -520.4714 and standard deviation of 2152.891 with a range negative value of -12757.67 and 141.3785. Moreover firms under this sector takes average of 218.21 days to sell their inventories with 391.58 days of standard deviation whereas minimum time that firm takes is of 47 days and maximum is of 2141 days, which is considered as long period of time for a firm to convert its inventory into sales.

Besides this, firms had an average of 6579.745 days with volatility of 30442.94 days to receive payment from customer. Furthermore, firms under this sector waited for an average of 758.5 days in order to make payment to its suppliers having standard deviation of 2468 day.As far as control variables are concerned firms' result showed mean value of 6.439 of firm size with a maximum value of 7.92 and minimum value of 3.48. Moreover DR showed average of 0.228 .

Table 2. Hausman's Specification Test

\begin{tabular}{|c|c|c|c|c|c|}
\hline D.V & I.V & Chi-Square & P-Value & Hypothesis & Model \\
\hline GOI & $\begin{array}{c}\text { AIF } \\
\text { SIZE } \\
\text { SG } \\
\text { DR }\end{array}$ & 26.977300 & 0.000 & Do not Rejected & Random Effect Model \\
\hline GOI & $\begin{array}{c}\text { AFF } \\
\text { SIZE } \\
\text { SG } \\
\text { DR }\end{array}$ & 9.800539 & 0.0439 & Do not reject & Random Effect Model \\
\hline GOI & $\begin{array}{c}\text { CCC } \\
\text { SIZE } \\
\text { SG } \\
\text { DR }\end{array}$ & 18.720132 & 0.0009 & Do not reject & Random Effect Model \\
\hline GOI & $\begin{array}{c}\text { INVD } \\
\text { SG } \\
\text { DR }\end{array}$ & 2.319294 & 0.5088 & Rejected & Fixed Effect Model \\
\hline GOI & $\begin{array}{c}\text { PP } \\
\text { SIZE } \\
\text { SG } \\
\text { DR }\end{array}$ & 18.212 & 0.0011 & Do not reject & Random Effect Model \\
\hline GOI & $\begin{array}{c}\text { RP } \\
\text { SIZE } \\
\text { SG } \\
\text { DR }\end{array}$ & 0.411145 & 0.9816 & Rejected & Fixed Effect Model \\
\hline
\end{tabular}

This table shows the results of Hausman's Specification Test that specifies random effect or fixed effect model is appropriate.

In random effect model GOI is significantly impacting AIP (Aggressive Investment Factor/ Policy), AFF (Aggressive Financing Factor/Policy), CCC, PP, Size, SG, DR reflecting p-value of $0.000,0.0439,0.0009$ and 0.0011 respectively, therefore we do not reject null hypothesis because random effect model is appropriate. Whereas GOI is not significantly impacting RP, size, SG and DR reflecting p-value of 0.98 , so we reject null hypothesis, which specifies that fixed effect model is appropriate. While checking Hausman's test of INVD along with its control variables that are Size, SG, and DR, issue of multicollinearity was observed therefore one control variable size for that particular model was dropped (See Table 2). Table 3 represents the analysis regarding Working Capital Management \& Profitability of the firms under automobile sector. 
Table 3 shows statistical results of pooled regression of all variables. The p-value (0.22) of AIF shows that model is not significant when t- test (-1.222) of AIF shows negative coefficient of -1469.9 that means AIF has negative relationship with GOI. Moreover the p-value (0.0463) of AFF (Aggressive Financing Factor/Policy) shows statistical significant model having positive coefficient of 2532.14 which indicates that there is positive relationship between GOI and AIF.

Table 3. Regression results Working Capital Management and Profitability

\begin{tabular}{|c|c|c|c|c|}
\hline Variable & $B$ & $E$ & t-stat & Prob. \\
\hline C & -11966.62 & 1809.695 & -6.612506 & 0.0000 \\
\hline AIF & -1469.908 & 1202.265 & -1.222616 & 0.2272 \\
\hline SIZE & 2011.492 & 252.2147 & 7.975313 & 0.0000 \\
\hline SG & $-4.33 E-05$ & 9.86E-06 & -4.390269 & 0.0001 \\
\hline DR & 618.6937 & 620.0850 & 0.997756 & 0.3232 \\
\hline \multicolumn{5}{|l|}{$R^{2} 0.6574$} \\
\hline C & -16059.08 & 2250.898 & -7.134520 & 0.0000 \\
\hline AFF & 2532.144 & 1239.243 & 2.043299 & 0.0463 \\
\hline SIZE & 2416.940 & 313.2291 & 7.716206 & 0.0000 \\
\hline SG & $-6.02 \mathrm{E}-05$ & 9.89E-06 & -6.086870 & 0.0000 \\
\hline DR & -1902.273 & 1389.660 & -1.368876 & 0.1772 \\
\hline \multicolumn{5}{|l|}{$R^{2} 0.6742$} \\
\hline C & -16574.17 & 1629.401 & -10.17194 & 0.0000 \\
\hline $\mathrm{CCC}$ & -0.353460 & 0.077302 & -4.572482 & 0.0000 \\
\hline SIZE & 2628.939 & 252.7491 & 10.40138 & 0.0000 \\
\hline SG & $-6.62 \mathrm{E}-05$ & 8.17E-06 & -8.111914 & 0.0000 \\
\hline DR & -108.7572 & 553.6260 & -0.196445 & 0.8451 \\
\hline \multicolumn{5}{|l|}{$R^{2} 0.7511$} \\
\hline C & 4610.917 & 1576.150 & 2.925430 & 0.0052 \\
\hline INVD & -5.328893 & 0.412873 & -12.90685 & 0.0000 \\
\hline SIZE & -656.7734 & 241.1029 & -2.724038 & 0.0089 \\
\hline SG & 1.55E-05 & $6.52 \mathrm{E}-06$ & 2.381714 & 0.0211 \\
\hline DR & 1203.907 & 304.9836 & 3.947448 & 0.0002 \\
\hline \multicolumn{5}{|l|}{$R^{2} 0.9185$} \\
\hline C & -17053.26 & 1961.556 & -8.693744 & 0.0000 \\
\hline PP & 0.288151 & 0.085343 & 3.376378 & 0.0014 \\
\hline SIZE & 2696.105 & 305.5799 & 8.822913 & 0.0000 \\
\hline SG & $-6.75 \mathrm{E}-05$ & $9.49 \mathrm{E}-06$ & -7.107442 & 0.0000 \\
\hline DR & 11.04476 & 598.4329 & 0.018456 & 0.9853 \\
\hline \multicolumn{5}{|l|}{$R^{2} 0.7125$} \\
\hline C & 686.3313 & 391.0713 & 1.755003 & 0.0854 \\
\hline $\mathrm{RP}$ & -0.052970 & 0.001155 & -45.84917 & 0.0000 \\
\hline SIZE & -107.7046 & 60.62071 & -1.776696 & 0.0817 \\
\hline SG & 2.70E-06 & $1.74 \mathrm{E}-06$ & 1.552159 & 0.1269 \\
\hline $\mathrm{DR}$ & 41.55175 & 96.73660 & 0.429535 & 0.6694 \\
\hline $\mathrm{R}^{2} 0.99$ & & & & \\
\hline
\end{tabular}

This table shows results of working capital management on firms' performance using pooled regression method. 
CCC shows that model is statistical significance with is $\mathrm{p}$ value of 0.0000 , indicating negative coefficient of -0.353460 which shows that there is negative relationship between firms CCC and GOI with 75\% of variation which is explained by R- square. This study also covers other components of CCC (i.e. INVD, RP and PP) and their relationship with GOI.

Furthermore, Statistical model of INVD shows that INVD is significant having $\mathrm{p}$ value of $(0.0000)$ and fit is showing negative coefficient of -5.328893 , which shows that there is negative relationship of INVD and GOI. Size, SG and DR control variable also showed significance with the model. Regression results between PP and profitability shows that regression model is significant with $p$ value of $(0.0014)$, whereas t-test shows positive coefficient of 0.288151 . The results shows positive relationship between PP and GOI. More table 3 also shows results of regression between receivable collection period and profitability and it is shown that RP is significant. The t test of RP shows negative coefficient of -0.0529 . Result indicated $p$ value of $(0.0000)$ which indicate weak relationship of RP with GOI under this sector.

Table 4: Descriptive Statistics of Food Sector

\begin{tabular}{ccccc}
\hline Variables & Minimum & Maximum & Mean & SD \\
\hline AIF & 0.254117 & 0.744362 & 0.489180 & 0.122429 \\
AFF & 0.088965 & 0.875985 & 0.434882 & 0.171424 \\
CCC & -10230975 & -141841.00 & -709186.8 & 1753582. \\
DR & 0.000160 & 0.727037 & 0.335343 & 0.207525 \\
GOI & -0.550000 & 35.19000 & 22.19481 & 7.924653 \\
INVD & 29.00000 & 249.0000 & 105.0779 & 50.72884 \\
PP & 2.014105 & 126.1215 & 31.64494 & 22.95639 \\
RP & 4.000000 & 91.00000 & 27.74026 & 18.57800 \\
SG & 365109.0 & $1.12 \mathrm{E}+08$ & 12177101 & 24930296 \\
SIZE & 5.562424 & 8.050738 & 6.535709 & 0.637128 \\
\hline
\end{tabular}

This table shows descriptive statistics of food sector.

Table 4 shows descriptive statistics based on data collected from food sector of Pakistan of 7 companies for period of 2006 to 2016 with total of 77 observations. The GOI represents mean value of 22.1948 and standard deviation of 7.924 with a range of -0.5500 and 35.190 respectively. The degree of aggressive investment factor shows average mean value of 0.489 whereas degree of aggressiveness of financing factor shows average mean value of 0.43488 .

CCC showed negative mean value of -709186.8 and SD of 1753582 with a range negative value of -10230975 and -14841.00 . Moreover firms under this sector takes average of 105.077 days to sell their inventories with 50.7288 days of SD whereas minimum time that firm takes is of 29.00 days and maximum is of 249.00 days, which is 
considered as long period of time for a firm to convert its inventory into sales. Besides this, firms had an average of 28 days with volatility of 18.57 days to receive payment from customer. The minimum time is of days and maximum time is 91 days taken to collect from account receivable. Furthermore, firms under this sector waited for an average of 32 days in order to make payment to its suppliers having SD of 23 day. Firms shortest time recorder to make their payments was of 2 days and longest period recorded was of 126 days.

Table 5. Hausman's Specification Test

\begin{tabular}{|c|c|c|c|c|c|}
\hline D.V & I.V & Chi-Square & P-Value & Hypothesis & Model \\
\hline GOI & $\begin{array}{c}\text { AIF } \\
\text { SIZE } \\
\text { SG } \\
\text { DR }\end{array}$ & 9.3023 & 0.054 & Rejected & $\begin{array}{l}\text { Fixed Effect } \\
\text { Model }\end{array}$ \\
\hline GOI & $\begin{array}{c}\text { AFF } \\
\text { SIZE } \\
\text { SG } \\
\text { DR }\end{array}$ & 62.342 & 0.000 & Do not reject & $\begin{array}{c}\text { Random Effect } \\
\text { Model }\end{array}$ \\
\hline GOI & $\begin{array}{c}\text { CCC } \\
\text { SIZE } \\
\text { SG } \\
\text { DR }\end{array}$ & 1.604 & 0.808 & Rejected & $\begin{array}{l}\text { Fixed Effect } \\
\text { Model }\end{array}$ \\
\hline GOI & $\begin{array}{c}\text { INVD } \\
\text { SIZE } \\
\text { SG } \\
\text { DR }\end{array}$ & 37.668 & 0.000 & Do not reject & $\begin{array}{c}\text { Random Effect } \\
\text { Model }\end{array}$ \\
\hline GOI & $\begin{array}{c}\text { PP } \\
\text { SIZE } \\
\text { SG } \\
\text { DR }\end{array}$ & 2.451 & 0.6533 & Rejected & $\begin{array}{l}\text { Fixed Effect } \\
\text { Model }\end{array}$ \\
\hline GOI & $\begin{array}{c}\text { RP } \\
\text { SIZE } \\
\text { SG } \\
\text { DR }\end{array}$ & 1.6043 & 0.808 & Rejected & $\begin{array}{l}\text { Fixed Effect } \\
\text { Model }\end{array}$ \\
\hline
\end{tabular}

This table shows the result of Hausman Specification Test which specifies either random effect or fixed effect model is the most appropriate.

As far as control variables are concerned firms' recorded mean value of 6.53 of firm size with a maximum value of 8.05 and minimum value of 5.56. Moreover DR and SG showed average of 0.333 and 1217710 respectively. In random effect model GOI is not significantly impacting AIF (Aggressive Investment Factor/Policy), CCC, PP, RP, Size, SG, DR reflecting $\mathrm{p}$ value of $0.054,0.808,0.6533 \& 0.808$ respectively, therefore we reject null hypothesis Whereas GOI is significantly impacting AFF (Aggressive Financing Factor/Policy), INVD, size, SG and DR reflecting probability value of 0.000 , so we do not reject null hypothesis, which specifies that random effect model is appropriate (See Table 5). 
Table 6. Regression between Working Capital Management and profitability

\begin{tabular}{|c|c|c|c|c|}
\hline \multicolumn{5}{|c|}{ DV(GOI) } \\
\hline Variable & $B$ & $E$ & t-stat & Prob. \\
\hline Constant & -8.231320 & 12.97796 & -0.634254 & 0.5281 \\
\hline AlF & -3.376987 & 5.235427 & -0.645026 & 0.5211 \\
\hline SIZE & 5.572748 & 2.004245 & 2.780473 & 0.0071 \\
\hline SG & $-1.29 \mathrm{E}-08$ & 3.63E-08 & -0.354170 & 0.7243 \\
\hline DR & -12.48624 & 4.383422 & -2.848514 & 0.0059 \\
\hline \multicolumn{5}{|l|}{$R^{2} 0.8669$} \\
\hline C & 28.98714 & 9.217934 & 3.144646 & 0.0024 \\
\hline AFF & -14.52055 & 3.581406 & -4.054428 & 0.0001 \\
\hline SIZE & 0.396621 & 1.401278 & 0.283042 & 0.7780 \\
\hline SG & 9.00E-08 & $3.20 \mathrm{E}-08$ & 2.807786 & 0.0064 \\
\hline DR & -12.42122 & 3.066796 & -4.050228 & 0.0001 \\
\hline \multicolumn{5}{|l|}{$R^{2} 0.399$} \\
\hline C & -9.509085 & 13.07710 & -0.727155 & 0.4697 \\
\hline $\mathrm{CCC}$ & $-2.88 \mathrm{E}-07$ & 4.94E-07 & -0.583974 & 0.5612 \\
\hline SIZE & 5.484190 & 1.986755 & 2.760375 & 0.0075 \\
\hline SG & $-3.82 \mathrm{E}-08$ & $6.11 \mathrm{E}-08$ & -0.625496 & 0.5338 \\
\hline DR & -11.56579 & 4.199037 & -2.754390 & 0.0076 \\
\hline \multicolumn{5}{|l|}{$R^{2} 0.8667$} \\
\hline C & 5.758553 & 9.952693 & 0.578592 & 0.5647 \\
\hline INVD & 0.009901 & 0.012520 & 0.790800 & 0.4317 \\
\hline SIZE & 3.207742 & 1.527303 & 2.100266 & 0.0392 \\
\hline SG & 2.41E-08 & 3.32E-08 & 0.725501 & 0.4705 \\
\hline DR & -17.48065 & 3.103301 & -5.632921 & 0.0000 \\
\hline \multicolumn{5}{|l|}{$R^{2} 0.301$} \\
\hline C & -8.643695 & 13.02059 & -0.663848 & 0.5091 \\
\hline PP & 0.003021 & 0.021181 & 0.142618 & 0.8870 \\
\hline SIZE & 5.326441 & 1.972174 & 2.700797 & 0.0088 \\
\hline SG & -1.08E-08 & 3.73E-08 & -0.288134 & 0.7741 \\
\hline DR & -11.74397 & 4.244321 & -2.766985 & 0.0073 \\
\hline \multicolumn{5}{|l|}{$R^{2} 0.868$} \\
\hline C & -3.507523 & 13.45150 & -0.260753 & 0.7951 \\
\hline $\mathrm{RP}$ & -0.037733 & 0.029660 & -1.272184 & 0.2078 \\
\hline SIZE & 4.640547 & 2.020535 & 2.296692 & 0.0248 \\
\hline SG & 1.56E-09 & 3.66E-08 & 0.042543 & 0.9662 \\
\hline DR & -10.73281 & 4.219727 & -2.543485 & 0.0133 \\
\hline$R^{2} 0.872$ & & & & \\
\hline
\end{tabular}

This table shows results of working capital management on firms' performance using pooled regression method. 
Table 6 shows the pooled regression results of all variables of study. The $\mathrm{p}$ value (0.5211) of AIP shows that model is not significant when t- test (-0.645026) of AIP shows negative coefficient of -3.376 indicating negative relationship between AIP and GOI. Moreover table 5 states results reflecting effects of AFF (Aggressive Financing Factor/ Policy) on profitability and its $p$ value $(0.0001)$ shows statistical significant model that indicates that there is negative relationship between profitability (GOI) and AIF (Aggressive Investment Factor/Policy).

The $\mathrm{p}$ value of CCC shows that model is not statistical significant under food sector, which indicate negative relationship between firms CCC and GOI with negative coefficient of -2.88. This study also covers other components of CCC (i.e INVD, RP and PP) and their relationship with GOI. The Statistical results of INVD shows that INVD is not significant having $\mathrm{p}$ value of (0.4317) which is more than 0.05 and further it is showing positive coefficient of 0.0099 , which shows that there is positive relationship of INVD and GOI. Results between PP \& GOI reflects that regression model is not significant with p value of $(0.88)$, whereas t-test shows positive coefficient of 0.003021 . The results show relative positive relationship between PP and GOI.Moreover it is shown that RP is not significant. Result indicated $p$ value of (0.2078) which indicate weak relationship of receivable collection period with GOI under this sector.

Overall, the results for food sector states negative relationship of AIF and AFFwith GOI. Al- Shubiri, (2011) found similar results between profitability and aggressive financing policy. The results for CCC revealed relatively negative relationship of CCC and GOI which contradict the results found by Abuzayed, (2012) and Gill et al. (2010). Cash Conversion Cycle are concerned negative relationship was observed of INVD under automobile sector showing consistency with the study done by Rehman and Nasr, (2007) and positive relation of food sector which is supported by the results provided by Abuzayed, (2012).

\section{CONCLUSION}

The study aims to focus on working capital management policy from aggressive perspectives and profitability. The results that automobile sectors revealed are that well designed working capital policy can leads to increase in profitability of firms. However results for food sector stated negative relationship of AIF (aggressive investment factor/ policy), AFF (aggressive financing factor/policy) with GOI (gross operational income. This result means with increase in AIF, and AFF will lead to decrease in profitability of firms under food sector. Further the relationship of working capital management and profitability is discussed by CCC and its other components. RCP and GOI in this study under both sectors showed negative relationship of RCP with GOI which means that increase in receivable collection period may lead to decrease the profitability as firms will take longer period of time to receive the payment from customers.

Financial managers of firms should focus on working capital management policies and components if they want to achieve sustainable financial growth, they should focusses on cash generation aspects from operations point of view. This study can help 
higher management of firm in decision making stating clearly about how to perform well to enhance financial health of company, which can encourage investors to invest in companies having sound market standing. For every business rolling of money in order to achieve financial stability like as result suggests negative relationship between GOI and CCC. It is important for firm to have efficient working capital management like in food sector it may result in risk or decrease in profitability if a firm tends to have more days to sell its inventory and receive payment from its customer late because food sector involves stock and inventory which tends to expire quickly and bulk buying involves more chances of damage if firm is unable to sell inventory on timely basis. Similarly for automobile bulk buying may result in sell of inventory late, which may result in price fluctuations of machines and parts of automobiles.

\section{REFERENCES}

Abuzayed, B. (2012). Working Capital Management and Firms' Performance in Emerging Markets: The Case of Jordan. International Journal of Managerial Finance. Vol. 8(2): 155-179. doi: https://doi.org/10.1108/ 17439131211216620.

Agha, H. (2014). Impact of Working Capital Management on Profitability. European Scientific Journal. Vol. 10(1): 71-80.

Al-Shubiri, F. N (2011). Analysis the Relationship between Working Capital Policy and Operating Risk: An Empirical Study on Jordanian Industrial Companies. Hebron University Research Journal. Vol. 6(1): 287-306.

Chang, H. J. (2012). The Manufacturing Sector and the Future of Malaysia's Economic Development. Jurnal Pengurusan (UKM Journal of Management). Vol. 35: 3-12.

Christopher, S. B., \& Kamalavalli, A. L. (2009). Sensitivity of Profitability to Working Capital Management in Indian Corporate Hospitals. Working Paper, NGM College. Retrieved from: http://papers.ssrn.com/sol3/papers. cfm?abstract_id=1331500.

Deloof, M. (2003). Does Working Capital Management Affect Profitability of Belgian firms? Journal of business finance \& accounting. Vol. 30(3-4): 573-588. doi: https:// doi.org/ 10.1111/1468-5957.00008).

Gill, A., Biger, N., \& Mathur, N. (2010). The Relationship Between Working Capital Management and Profitability: Evidence from the United States. Business and Economics Journal. Vol. 10(1): 1-9.

Khidmat, W., \& Rehman, M. (2014). Impact of Liquidity and Solvency on Profitability Chemical Sector of Pakistan. Economics Management Innovation. Vol. 6(3): 34-67.

Lazaridis, I., \& Tryfonidis, D. (2006). Relationship Between Working Capital Management and Profitability of Listed Companies in the Athens Stock Exchange. Journal of Financial Management and Analysis. Vol. 19 (1): 61-70.

Latif, A. S., \& Abdullah, F. (2015). The Effectiveness of Corporate Governance in Constraining Earnings Management in Pakistan. The Lahore Journal of Economics. Vol. 20(1): 135-150.

Mojtahedzadeh, V., Tabari, S., \& Mosayebi, R. (2011). The Relationship between Working Capital Management and Profitability of the Companies (Case Study: Listed 
Companies on TSE). International Research Journal of Finance and Economics. Vol. 76(1): 158-166.

Mohamad, N. E. A. B., \& Saad, N. B. M. (2010). Working Capital Management: The Effect of Market Valuation and Profitability in Malaysia. International Journal of Business and Management. Vol. 5(11): 140-150.

Myers, S. C., \& Majluf, N. S. (1984). Corporate Financing and Investment Decisions When Firms Have Information That Investors Do not Have. Journal of Financial Economics. Vol. 13(2): 187-221. doi: https://doi.org/10.1016 /0304-405X(84)90023-0.

Nazir, M. S., \& Afza, T. (2009). Impact of Aggressive Working Capital Management Policy on Firms' Profitability. IUP Journal of Applied Finance. Vol. 15(8): 19-30.

Ohlson, J. A. (1980). Financial Ratios and The Probabilistic Prediction of Bankruptcy. Journal of accounting research. Vol. 18 (1): 109-131.

Padachi, K. (2006). Trends in Working Capital Management and Its Impact on Firms' Performance: an Analysis of Mauritian Small Manufacturing Firms. International Review of Business Research papers. Vol. 2(2): 45-58.

Pouraghajan, A., \& Emamgholipourarchi, M. (2012). Impact of Working Capital Management on Profitability and Market Evaluation: Evidence from Tehran Stock Exchange. International Journal of Business and Social Science. Vol. 3(10). doi: https://doi. org/10.1016/j.jfineco.2016.07.001

Raheman, A., \& Nasr, M. (2007). Working Capital Management and Profitability-Case of Pakistani Firms. International Review of Business Research Papers. Vol. 3(1): 279-300.

Raheman, A., Afza, T., Qayyum, A., \& Bodla, M. A. (2010). Working Capital Management and Corporate Performance of Manufacturing Sector in Pakistan. International Research Journal of Finance and Economics. Vol. 47(1): 156-169.

Samiloglu, F., \& Demirgunes, K. (2008). The Effect of Working Capital Management on Firm Profitability: Evidence from Turkey. The International journal of applied Economics and Finance. Vol. 2(1): 44-50.

Siddique, M. M., \& Khan, S. M. (2008). Analyzing Working Capital Management: Evidence from Dhaka Stock Exchange. The Journal of Nepalese Business Studies. Vol. 3 (1): 41-50.

Singhania, M., Sharma, N., \& Rohit, J. Y. (2014). Working Capital Management and Profitability: Evidence from Indian Manufacturing Companies. Decision. Vol. 41(3): 313-326.

Singh, J. P., \& Pandey, S. (2008). Impact of Working Capital Management in the Profitability of Hindalco Industries Limited. ICFAI journal of financial Economics. Vol. 6(4): 410-420.

Salawu, R. O., \& Ile-Ife, N. (2007). An Empirical Analysis of The Capital Structure of Selected Quoted Companies in Nigeria. The International Journal of Applied economics and finance. Vol. 1(1): 16-28.

Tauringana, V., \& Adjapong Afrifa, G. (2013). The Relative Importance of Working Capital Management and Its Components to SMEs' Profitability. Journal of Small Business and Enterprise Development. Vol. 20(3): 453-469.

Usama, M. (2012). Working Capital Management and Its Affect on Firm's Profitability and Liquidity: In Other Food Sector of (KSE) Karachi Stock Exchange. Oman Chapter 
of Arabian Journal of Business and Management Review. Vol. 1(12): 62-73. DOI: $10.12816 / 0002232$.

Van Horne, J. C., \& Wachowicz, J. M. (2000). Fundamentals of Financial Management. New Jersey: Prentice Hall.

Weinraub, H. J., \& Visscher, S. (1998). Industry Practice Relating to Aggressive Conservative Working Capital Policies. Journal of Financial and Strategic Decision. Vol. 11(2): 11-18.

Zirayawati, M.A., Annuar, M. N., Taufiq, H., \& Rahim, A. A. S. (2009). Working Capital Management and Corporate Performance: A Case Study of Malaysia. J. Modern Accounting and Auditing. Vol. 5(11): 511-520. 